\title{
Government of India Endeavors for Vocational Education, Training and Skill Development
}

\section{* Dr. Ramakant Barua}

\section{Abstract}

Vibrant communities and a prosperous society are built on the foundation of a strong education system. Skills and knowledge are key drivers of macro-economic growth and socioeconomic stability. Appropriate policies for the skill development occupy a dominant place in the development of economy. According to five year plan, India has set aggressive goals for faster and sustainable economic growth of nation. With the demographic dividend, India needs to impart adequate skills to its workforce. Skill development has emerged as national priority for which a number of measures have been taken and in process for future. The National Policy on Skill Development and Entrepreneurship, 2015 will be to meet the challenge of skilling at scale with speed and standard (quality). It will aim to provide an umbrella framework to all skilling activities being carried out within the country, to align them to common standards and link the skilling with demand centres. In addition to laying down the objectives and expected outcomes, the effort will also be to identify the various institutional frameworks which can act as the vehicle to reach the expected outcomes. The national policy will also provide clarity and coherence on how skill development efforts across the country can be aligned within the existing institutional arrangements.This policy will link skills development to improved employability and productivity. In this context, present paper studies and analyses the present status of skill development and to highlight the Government Endeavors for 'Vocational Education and Training' programme in India.

Keywords: Skill, employment, demographic dividend, training, India a manufacturing hub, Make inIndia, NarendraDamodardasModi, Prime Minister of India.

*Senior Consultant (Monitoring) in RMSA-TSG, Ministry of Human Resources Development, Government of India, New Delhi-110001 


\section{Skill Development in India}

India is in the process of changing gears on development and the next ten years is going to see a lot of activity on several fronts like manufacturing, construction, retail and services. The country did begin to show signs of momentum but began to lose steam mid-way into the UPA II regime. With the new government in place, the hope of India reviving its growth story north of 8 percent seems attainable, post FY'16.

But the India success story pretty much depends upon the number and quality of its workforce. The demographics are exciting. With 54 percent of its 1.2 billion population under the age of 24, India is the youngest country in the world. Compare this with 30 years in China, 38 years in Europe and 41 years in Japan.

It is estimated that by 2020 , the global shortage of skilled manpower is likely to touch 56.5 million, while India is likely to have a surplus exceeding 47 million. Those are significant numbers that should be getting us all excited. But is it?

If India is to realize its dream of becoming an emerging superpower over the next two decades, then it is time to do a reality check on our education system and see how prepared our system is to meet the demand for skill development of our potential workforce.

\section{Revamp in education system needed}

India has to seriously re-look at the education system and re-align the same to meet the challenges of the coming time. Gone are the days of rote learning and studying to attain marks in an examination. The contemporary demand from a student is to have good language, comprehension, analytical, and mathematical skills.

While the nation would like us to believe that our education system more than adequately matches up to global standards and look at the IITs to further boost our confidence, the reality is that Indian students stood second last out of 73 countries that participated in the Programme for International Student Assessment (PISA), which is a global evaluation process for students organized by the Organization for Economic Co-operation and Development (OECD). 
The Indian students fared badly on reading, math and science abilities. On most of the points we were in the bottom three. In contrast, Chinese students were in the top three in most of the sections. India prides itself as an English-speaking nation but even on this, the Indian students fared badly. This was in 2010.

So how did India react? We trashed the test and decided not to send Indian students for the next round of PISA! No evaluation, no introspection and no correction. The system carries on.

\section{Ground reality}

We need to understand that there is a major challenge in achieving standardization in education. The problem is that it is a State subject and each State is still stuck trying to meet its vote bank expectations and insisting on retaining the mother-tongue as the medium of instruction. We need to accept that English is here to stay and English is going to continue to be the international language of choice. India can not afford to have people either not speaking or speaking with a heavy accented English.

In another decade China will be far superior in English communication skills, while they are already ahead on comprehension, analytical and mathematical skills, at the school level. India has to urgently introduce spoken English in all schools and this has to be national priority. The corporate sector won't wait and nor will the nation. Ultimately, those who speak and comprehend good English will always be preferred over those do not. Would the States like to deny their future generation this opportunity?

We also need to understand that education cannot follow a one-sizefits-all policy. Students have differing aptitude and comprehension levels and we need to have a system that recognizes these varying levels and offer options that can match his interest and aptitude. There is no point in forcing a 15 -year-old to learn maths or science if his interest is in art. Therefore, there is an urgent need to have several streams of learning options in the post-middle school level. Those that have an interest and aptitude for higher learning can pursue the regular programme. 
However, there is a large section of students who do not have the interest nor aptitude for higher learning and would prefer to follow a vocational stream. It is this section that will form the future base of the skilled worker pyramid. India has to tap this segment at the school level and then nurture them through a progressive skills acquisition programme.

\section{Have the ITIs really met expectations?}

The Industrial Training Institutes (ITI) was set up to meet the need for skilled labour in the manufacturing and services sector. With this mind, the Central Government went about setting up ITIs in various States across the country. However, the ITIs have not been able to fully match the expectations of the industry. While the infrastructure is fairly widespread, little attempt has been made to understand what level of skill the industry really wants. Each industry today has a different requirement and unfortunately, the ITIs have also followed a one size-fits-all approach.

There has been little work on understanding trainee expectation and trying to match the employer demand. Also, there has been very little study to find out how many have actually been employed, how many have actually continued to remain employed and how many have left as a result of an expectation mismatch.

In addition, the ITIs have paid very little attention to English speaking and soft skills development, as a result a trainee finds it difficult to adjust in the work environment from day one, as the factory cannot afford to train him on these. There is also very little by way of mentoring to assist him to address issues pre and postemployment.

The ITI is an excellent platform to build the base that India needs. We need to improve the infrastructure, the teaching faculty and align the teaching process and content with the industry. This can best be achieved if the interface with industry is increased and brought in to suggest the curriculum, as per their requirement. Additionally, the teaching programme at the ITI must include a frequent on-site training at the industry level, as per the trainee's skill and interest. 
For example, a trainee may want to work in an electronics factory. There is no point in sending him to a machine tool factory. The industry must be encouraged to pre-recruit the trainee and offer stipend through his learning period at the ITI. This will incentivize the trainee, as also familiarize him with real time environment at the work level. This will help in his acclimatization process and ensure that he is able to contribute from day one of regular employment.

The government of India has ambitious plans to upgrade its existing ITIs and add another 1500. In addition, the plan is to set up 50,000 Skill Development Centres (SDC), under the PPP mode.

\section{National Skills Development Programme}

The Government of India has set up the National Skills Development Council (NSDC), in collaboration with the private sector, and is supported with funding from international agencies like the World Bank. The NSDC has joined hands with Accenture for design and development of a customized skills development programme that will meet the needs of the industry in coming times.

The programme is ambitious and plans to skill 500 million youth by 2020. The NSDC has taken the right approach of understanding the prevailing challenges and then preparing a roadmap that is aligned with industry needs and trainee expectations. Hopefully, the youth will be able to match up to the opportunity and contribute in realizing India's potential as a developed nation.

\section{Historical Background of Technical Education in India}

With British rule came the establishment of technical centers in India as they needed skilled labor for constructing roads, buildings and for other such works. Also, there was a requirement of skilled artisans and craftsmen to help the British army. Though superintending engineers, foremen and artificers were hired from Britain, skilled craftsmen were hired locally for all other low grade jobs. To improve their efficiency, they were given basic lessons in writing, reading, geometry and mechanics.

Also with the industrial revolution, the importance of technical education was felt because it brought the need of operating machines 
and completing the task skillfully within a short span of time. So, the perspective towards education started to change. Education in India that earlier used to focus more on personality development than skill was now focusing on the latter.

Though technical schools were present in Calcutta and Bombay even during 1825, an industrial school was established at Guindy, Madaras in 1842. To train civil engineers, the first engineering college was established in 1847 in Uttar Pradesh. In November 1856, the Calcutta College of Civil Engineering was established in Bengal. After a year, its name was changed to the Bengal Engineering College. With time and need, more and more such colleges came into existence in India. Great need of all kinds of engineers was felt after independence, so a number of engineering colleges were established keeping this in mind.

\section{Scope of Vocational or Technical Education in India}

Technology is touching every aspect of life and society. So, there is a dire need of backing up conventional study and teaching with technical education, as it will not only help in the development of the country, but also the person possessing those skills. A technically sound person is never short of jobs. Thus, technical education as per the needs of the present market will assist in uplifting society. Technical education is a part of education that is directly related to the gaining of information and skills needed in manufacturing and service industries.

In India, overall education can be divided into social, spiritual and vocational. Concerns related to society are covered under social education, personality development is the part of spiritual education and vocational education consists of technical education that further deals with branches like agriculture, medicine, engineering and commerce. Technical education is a skill-based education that primarily keeps the job prospects in mind. It provides training to the individual in a specific field. In India, the Vocational Education Program (VEP) was started in 1976-77 under the programme of Vocationalisation of Higher Secondary Education in general education institutions. The National Working Group on 
Vocationalisation of Education (Kulandaiswamy Committee, 1985 ) reviewed the Vocational Education Programme in the country and developed guidelines for the expansion of the programme. Its recommendations led to the development of the Centrally Sponsored Scheme (CSS) on Vocationalisation of Secondary Education, which started being implemented from 1988. Its purpose is to "enhance individual employability, reduce the mismatch between demand and supply of skilled manpower and provide an alternative for those pursuing higher education without particular interest or purpose."

For acquiring technical education, there are two structural streams in India - formal and informal. Polytechnics, Industrial Training Institutes (ITIs), Industrial Training Centers (ITCs), Centrally Sponsored Scheme of Vocationalisation of Secondary Education by the Ministry of Human Resource Development are few of the formal sources of technical education in India. Whereas self-learning and small private institutes providing short term technical course are covered under informal ones.

In the past few decades, India has seen a mushrooming of many small to medium technology-based enterprises because of the easy availability of labour. Though students are opting these formal technical institutes for training but interest of students in these institutes is quite less in India. Also the rate of enrollment in these vocational institutes is very low, as there is a high drop rate at secondary level in India.

Vocational training is given in class 11 and 12, but students who reach at this level focus on higher education rather than technical training. Moreover, employers look for candidates with strong academic record rather than just having a vocational training. Training institutes too lack trained staff and teachers. Most of the teachers who impart basic technical training are not well qualified. Also, we do not have quality institutions in India for technical education. Then the lack of interest and interaction from industry is another big challenge for the growth of technical education in India. Also, less emphasis is given on skill up-gradation during 
employment in India.

To overcome these hurdles, old curriculum must be updated with a new and advanced one. Also, new institutes must be set in to provide advance information regarding this field. Classes should be more interesting and interactive with full industry participation. Students must be made aware of their growth path in the selected stream.

It is not that our education system is full of flaws. We have a rich educational heritage and a very strong primary education system. Subject knowledge is extensively given in India, and Indians have vast theoretical knowledge as well. As compared to developed countries, India has a good number of higher educational institutions. But on the other hand, lack of an updated curriculum and specialized technical education are the flaws in our education system. Teachers do not play any role in addition to teaching. Once these hurdles are crossed, growth in technical education can be seen in India.

\section{Importance of Vocational Training in Generating Employment Government Endeavours}

Despite the fact that the Indian economy has witnessed a considerable growth in the last two decades, this growth rate has not been uniform. Underemployment, low educational levels, a high rate of dropouts and lack of proper vocational training which can provide better employment opportunities, are still prevalent. The shortage of skilled workforce is evident from the discrepancies of demand and supply in the market.

According to the reports of a Boston Consulting Group, India will have a surplus of 56 million working people while the global shortage of skilled working people will be 47 million by 2020. With a 'demographic dividend' of more than 50 percent of the population within the age bracket of 25, the 11th Five Year Plan identified the potential of India emerging as an important global entity in skill development. Currently only 10 percent of the youth population has proper vocational training. Realizing the importance of proper vocational training and skill development programs, the 11th Five Year Plan established the PM's National Council for Skill 
Development (for framing policies), the National Skill Development Coordination Board (for coordinating the various skill development programs), and finally the National Skill Development Agency (NSDA - a catalyst to enhance the skill development programs).

Later the PM's Council and the Coordination Board had been absorbed in NSDA, which is now empowered to serve as the flagship for countrywide skill development programs undertaken by the Government. The 12th Five Year Plan outlines strategies for further improving the vocational training programs at both the Center and State levels.

Some important vocational training programs undertaken by the Government

- Craftsmen Training Scheme(CTS): Under the Ministry of Labour and Employment, the CTS aim at providing vocational training to the school leavers and educated youths (so that they can meet the industrial requirements). There are separate reservations for the $\mathrm{SC} / \mathrm{ST}$, physically handicapped and women.

\section{- Modular Employable Skill (MES) based Training} Pgrograms: Under the Ministry of Labour and Employment, MES has been designed specifically through consultation with the Industries and backed by the opinions of the experts in the field of vocational training. MES aims at providing a 'minimum skill set' that is just sufficient to gain entry in the employment sector. MES is an extremely flexible program with the objective of providing vocational training to the school leavers, ITI graduates etc., to increase their chances of employment through optimal utilization of the existing infrastructures of the Government, private sector and the industries.

- National Rural Livelihoods Mission (NRLM)/AAJEEVIKA: The objective of this scheme is to harness the capabilities of the rural poor population by supplementing them with knowledge, skill sets, tools and finance so that they can have proper livelihood options. The primary target of this scheme is to deliver market driven skill training to the rural BPL youths in the age bracket of 18 to 35 years and provide placement in suitable sectors. 
- National Urban Livelihood Mission (NULM): An integral part of the SWARNA JAYANTI SHAHARI ROZGAR YOJANA (SISRY) under the Ministry of Housing and Urban Poverty Alleviation, NULM's objective is to provide the urban poor with proper vocational training so that they can undertake self-employment and increase their chances of employment in different sectors. The primary target of this project is the urban poor population below poverty line with special reservations for the SC/ST and women. A special 3\% reservation is also there for the physically challenged.

- Support to Training and Employment Program(STEP): Under the Ministry of Women and Child Development, STEP aims at upgrading skills of women converting them into viable assets for employment. This program also provides placements for women and access to credit facilities. Other than that this program has a complete package of support services, awareness generation, gender sensitization, educational programs, nutrition and nutrition oriented awareness program, legal literacy including day care facilities for dependent children.

- PARVAAZ: It provides comprehensive vocational training and education program for the rural below poverty line (BPL) areas. Operating under the Ministry of Rural Development, the primary objective is to include the BPL youths, minority youths especially school dropouts/left outs in the mainstream by providing them with a platform through extensive vocational training and educational programs and employment opportunities.

- Rural Self Employment Training Institutes(RSETI): The main objective of the RSETIs is to provide the rural BPL youths with free and unique, intensive, short term, residential, selfemployment training programs, which includes free food and accommodation so that they can undertake micro enterprises and wage-based employment.

- Polytechnics: Operating under the Ministry of HRD, Polytechnics provide three years diploma courses in conventional disciplines like civil, electrical and mechanical engineering and 
also on the emerging disciplines like electronics and computer science. The minimum eligibility is secondary level. Employment oriented curriculum is being implemented in the Polytechnics. A new plan of setting up of 300 new polytechnics is currently underway.

- Tool Rooms: 10 such MSME tool rooms have been set up with Indo-German and Indo-Danish collaborations. Tool Rooms offer short term courses on manufacturing of quality tools to the school dropouts to assist the MSMEs. Long term courses like 'Post Graduate Diploma on Tool Designing and CAD/CAM' are also available. The Tool Rooms have achieved almost 100\% placement with their long term course trainees in different industries

- UDAAN: Funded by the Ministry of Home Affairs, UDAAN is specially designed for Jammu and Kashmir, aiming at training 40,000 students in 5 years in various sectors including retail, IT and BPO.

There are other Government endeavours like ROSHNI and vocational training programs, exclusively designed for the rural youths of the Left Wing Extremism affected areas of India.

Challenges likely to be faced by the vocational training programs undertaken by the Government as per the $12^{\text {th }}$ Five Year Plan:

- Expansion of the various projects in remote and difficult areas through E-Learning, Internet and simulation packages

- Setting up of vocational training centers in underdeveloped areas

- Designing market oriented projects and extensive promotion of public private partnership

- Introducing AADHAR based tracking of the beneficiaries in pre and post placement programs

- Revamping the entire Employment Exchange Network to function as an effective human resource development centers

- Increase credibility of the certification procedure and streamlining it to avoid delays in granting certificates.

A strict monitoring of the funds released under various schemes and 
projects to ensure their proper utilization and avoiding any misappropriation. The target of the 12th Five Year Plan is to create 50 million employment opportunities in the non-agricultural sector with an equivalent supply of skilled manpower by the end of the plan. As evident from the above discussions, the ball has been set rolling. The Indian Bank has formulated an educational loan scheme for the underprivileged which is planned to cover tuition fee, exam fee, caution deposits, etc. The loan amount may vary from Rs 20,000 to Rs 1.5 lakh for a course of duration of more than one year. However, a more aggressive persuasion on the part of the Government is essential to generate 50 million work opportunities at the end of the 12th Five Year Plan.

\section{Conclusion}

There is need of reforms in industrial strategies to make India a manufacturing hub. Favorable industrial framework need to be established that should attract more and more domestic as well as foreign industrialists towards Indian Territory. Presently $80 \%$ of the workforce in India (rural and urban) doesn't possess any identifiable and marketable skills. Therefore, bridging this gap through various skill development initiatives could make India the global hub for skilled manpower, and also result in a surplus of skilled manpower of approximately 47 million 2020 (FICCI). Despite various efforts and investments in shaping the skills of a huge labor force there are grave drawbacks in the system. Even after the government investing a lot in training costs and infrastructure, creation of robust workforce for the industry is still a fantasy.

As a fast growing developing economy, besides white and blue collar, India also needs Grey collar- knowledge workers which include ICT skills, problem solving, analytical ad effective communication skills and rust collar-skilled workers at the grass root level in currently unorganized sector and unbenchmarked sectors like construction, agriculture and related trade. Government, industry leaders are constantly from time to time launching new skill development initiatives but somehow it is 
not reaching the casual workers who dominate the Indian workforce. Stakeholders (Industry leaders, Government etc) have realized that none of them can work in isolation. They will need to collaborate as the stake involved is huge.

\section{References}

Amitendu Palit, Skills Development in India: Challenges and Strategies Bhattacharyya R, (2012). The Opportunities and Challenges of FDI in Retail in India, IOSR Journal of Humanities and Social Science, 5(5), pp. $99-109$

Chatturvedhi Siddharth, Skill development for the youth-A Global Quest, AISECT University Journal Vol. II/Issue IV Sep. 2013.

Federation of Indian Chambers of Commerce and Industry, (FICCI 2010), The skill development landscape in India and implementing Quality skills training. Zugriff am 19.April 2012.

Federation of Indian Chambers of Commerce and Industry, (FICCI 2013), Sandhya Srinivasan, Skill Development Initiatives in India, ISAS Special Report, No. 15-11 July 2013.

FICCI , Skill development Sector Profile, FICCI, 2012 http HYPERLINK "http://www.ficci.com/sector/74/Project_docs/Sector Profile.pdf"://www.ficci.com/sector/74/ Project_docs/SectorProfile.pdf FICCI, (2010), The Skill Development Landscape in India and Implementing Quality Skills Training, New Delhi: Federation of Indian Chambers of Commerce and Industry.

Goyal Samridhi , Prabhjot Kaur, Kawalpreet Singh; Role of HR and Financial Services in Making "Make in India" Campaign a Success, IOSR Journal of Business and Management (IOSR-JBM), e-ISSN: 2278487X, p-ISSN: 2319-7668. Volume 17, Issue 2.Ver. IV (Feb.

2015

Hajela Ruchi, Skills knowledge and organizational performance, Paper no 111, November 2012), available at http://www.cardiff.ac.uk/socsi/ research/research centres/skope/publications/researchpapers/ WP111.pdf,

Hassan, Dr. M. Kabir The impact of globalization on the developing countries, Journal of Economic Cooperation Among Islamic Countries, 19, 1-2 (1998) 71-135

Indian Entrepreneurs in Import Substitution - Need of the Hour for Indian Economy, Mrs.KamnaDhawan, AISECT University Journal Vol. 
II/Issue IV Sep. 2013.

Kanchan Sonali, SakshiVarshney; Skill development initiatives and strategies, Asian Journal of Management Research, ,http://www.ipublishing.co.in/ajmrvol1no1/volfive/EIJMRS5242.pdf National Policy on Skill Development (2009). Ministry of Labour and Employment, Government of India..

PHDCCI Skill Development : Bridging Skills Deficit and Promoting Employability, PHD Chamber of Commerce and Industry, Apeejay Stya Education Research Foundation http://www.aserf.org.in/presentations/ Conf-SKD-Backgrounder.pdf

Report of the Committee on Unorganized Sector Statistics (2012, February), National Statistical Commission, Government of India. Retrieved from available at http://mospi.nic.in/mospi_new/upload/ nsc_report_un_sec_14 mar12.pdf?

Report of the Committee on Unorganized Sector Statistics (2012, February), National Statistical Commission, Government of India.

Yash Pal Sharma, "Skill Development Programmes In India" November $1-12,2010$, 


\section{Skill India to Leverage Make in India: Intiatives and Challenges - A Study on Problems of Entrepreneurs and Venture Capitalists in Bengaluru}

\section{* Dr. Guru Basava Aradhya.S \\ ** Mr. Vinay M R}

\section{Abstract}

Entrepreneurship is the backbone of any economy. Every stable government in the world has kept promoting entrepreneurship as one the main agenda in its policies and plan document. The new ventures developed through entrepreneurship have been reported to yield a wide spectrum of economic benefits through innovation, generation of new business, creation of new jobs, development of innovative products and services, and have also created the opportunity for future investment in the growth and development activities of the nation. Entrepreneur is a person who sets up a business or businesses, taking on financial risks in the hope of profit. The concept of innovation and newness is an integral part of entrepreneur. Indeed, innovation, the act of innovation is difficult task.

The Venture capital sector is the most vibrant industry in the financial markets today. Venture capital is finance provided by professionals who invests young, rapidly growing companies that have the potential to develop into significant economic contributors. A venture capitalist is an investor who either provides capital to startup ventures or supports small companies that wish to expand but do not have access to equities markets.

In this study descriptive analysis is done to find out various problems faced by venture capitalists and entrepreneurs in different stages of

* Professor, Department of Business Administration, Alva's Institute of Engineering and Technology, Shobhavana Campus, Mijar

Moodbidri-574225, M: 9731910916 ,

Email-Id: guruaradhya@gmail.com

** Student of $2^{\text {nd }}$ Semester MBA, Alva's Institute of Engineering and Technology, Shobhavana Campus, Mijar, Moodbidri-574225

M:8904526525,Email-Id:vinu.prasadmr.18@gmail.com 
venture capital financing. There could be various problems in different stages of venture capital, which are faced by both venture capitalists, which are faced by both venture capitalists and entrepreneurs. This paper is aimed from looking the problems from both venture capitalists and entrepreneurs and suggests some suitable strategies to minimize the problems. Data was collected separately from them. 5 (five) venture capitalists and 20 (twenty) entrepreneurs using a pre-tested and structured schedule in Bengaluru. Percentage analysis is exploited to derive the objectives. This paper would benefit e-retailers in understanding the obstacles and problems faced by venture capitalist and entrepreneurs in different stage. Knowledge, vision, meticulous planning, drive, dynamism, hard work, gambler's instinct and may be, a certain degree of ruthless for achieving results as per the plan of Venture capitalist and entrepreneur.

Keywords: Venture capitalist, financial market, entrepreneur

\section{Introduction}

Venture capital financing is emerging as a new institutional mechanism in the post-1990 period in India. The growth of this industry is as not expected as in the rest of the world. The reason for venture capital not being popular in India could be due to various reasons/factors or also may be due to various problems existing in the system being practiced here. There could be various problems in different stages of venture capital, which are faced by both venture capitalists, which are faced by both venture capitalists and entrepreneurs. This paper is aimed from looking the problems from both venture capitalists and entrepreneurs and suggests some suitable strategies to minimize the problems.

As a new technique of financing to inject long term capital into the small and medium sector, it has made notable contributions to its growth in the developed countries, particularly in the USA and UK. The nascent venture capital industry in India can profitably be drawn upon their experiences. Some of the characteristic features that distinguish venture capital from other investments are as follows. Venture capital is basically equity finance for relatively new 
companies when it is too early to go to the capital market to raise funds. It is a long term investment in growth-oriented small/medium firms. There is a substantial degree of active involvement of the venture capital institutions with the promoters of the venture capital undertakings. Venture capital is a type of private equity, a form of financing that is provided by firms or funds to small, early-stage, emerging firms that are deemed to have high growth potential, or which have demonstrated high growth (in terms of number of employees, annual revenue, or both).Venture capital financing involves high risk-return spectrum. The returns in such financing are essentially through capital gains at the time of exit from disinvestments in the capital market. Venture capital finance is not technology finance, though technology finance may form a subset of venture capital finance. Venture capitalists are willing to invest in such companies because they can earn a massive return on their investments if these companies are a success.

\section{Statement of the Problem}

It is a known fact, that the venture capital is successful in USA and in UK, but not in India. The reason for venture capital not being popular in India could be due to various reasons/factors or also may be due to various problems existing in the system being practised here. There could be various problems in different stage of venture capitalists and entrepreneurs. Hence, an attempt has been made here to find out various problems faced by venture capitalists and entrepreneurs in different stages of venture capital financing.

\section{Scope of Present Study}

For the purpose of this research, five venture capitalists were met and found out various problems faced by them in venture capital financing. It was also tried to find out the various problems faced by them at various stages of financing. About 20 entrepreneurs who have taken the help were also approached and tried to find out the various problems faced by them. However, the scope of present study is limited to venture capitalists and entrepreneurs of Bangalore city only. 


\section{Objectives of the study}

- To find out the various problems faced by the venture capitalists at various stages of financing

- To find out the various problems faced by the entrepreneurs at various stages of getting finance

- To suggest strategies to overcome the problems faced by venture capital institutions and the entrepreneurs who have taken the venture capital finance.

\section{Methods of Data Collection}

\section{Primary Data}

The primary data was collected from both venture capitalists and entrepreneurs using a structured questionnaire

\section{Secondary data}

The secondary data was collected from various financial periodicals, articles, newspapers and also from the websites of some of the institutions and entrepreneurs

\section{Sampling Plan}

The venture capitalists and entrepreneurs were selected at random and data was collected separately from them. 5 (five) venture capitalists and 20 (twenty) entrepreneurs were met and got the data from them. Convenient Random Sampling method was adopted.

\section{Limitations}

- Due to time constraint, only a small number of venture capitalists and entrepreneurs and got the data has been taken as sample for the study

- Since the data was collected through questionnaire, there is always the chance of bias and

- Present study was limited to Bangalore city only 


\section{Data Analysis of Entrepreneurs}

Table No. 1 : The profile of respondents

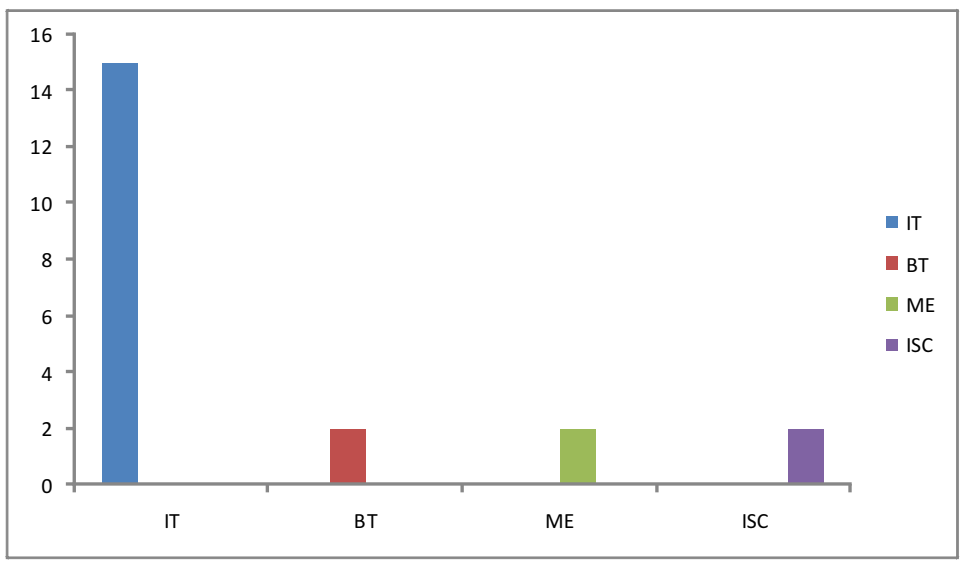

It can be observed in the Table No. 1 about 70 percent of the entrepreneurs are information technology based companies, 10 percent of the entrepreneurs are Bio-technology based, and Media/Entertainment based and Innovative shopping center based companies / organization

In Table No. 2 about 33 percent of the entrepreneurs are of the opinion that the venture capitalists lack technical expertise, 33 percent of the entrepreneurs are of the opinion that the venture capitalists are unaware about the latest technology. 9 percent of the entrepreneurs have at the opinion that the venture capitalists demand too many formalities to be followed while striking the deal. 5 percent of the entrepreneurs are at the opinion that the venture capitalists demand lot of supporting documents to be submitted, demand too high security. Because of the bad experiences faced from similar 
organizations in the past about 5 percent of the entrepreneurs face problems with venture capitalists in striking a deal. Another 5 percent of the entrepreneurs are at the opinion that the venture capitalists do not show positive approach. 5 percent of the entrepreneurs are at the opinion that frequent changes in government rules and regulations make it difficult for them to strike a deal with venture capitalists.

Table No. 2 : Problems faced while striking a deal with the venture Capitalists

\begin{tabular}{|l|l|l|l|}
\hline Sl.No & Nature of the problem & In Number & In percent \\
\hline 1 & $\begin{array}{l}\text { Lack of technical expertise in the } \\
\text { company }\end{array}$ & 7 & 33 \\
\hline 2 & $\begin{array}{l}\text { Lot of supporting documents to be } \\
\text { submitted }\end{array}$ & 1 & 5 \\
\hline 3 & $\begin{array}{l}\text { Frequent changes in government rules } \\
\text { and regulations }\end{array}$ & 1 & 5 \\
\hline 4 & Unaware about latest technology & 7 & 33 \\
\hline 5 & $\begin{array}{l}\text { Bad experience faced from similar } \\
\text { organizations in the past, the venture } \\
\text { capitalists do not show positive } \\
\text { approach }\end{array}$ & 1 & 55 \\
\hline 6 & $\begin{array}{l}\text { Non- cooperation from staff of } \\
\text { company }\end{array}$ & 1 & 5 \\
\hline 7 & Security demand ed is too high & 1 & 5 \\
\hline 8 & Too many formalities to be followed & 2 & 9 \\
\hline
\end{tabular}

Source : Field Survey

Graph showing Problems faced while striking a deal with the venture Capitalists

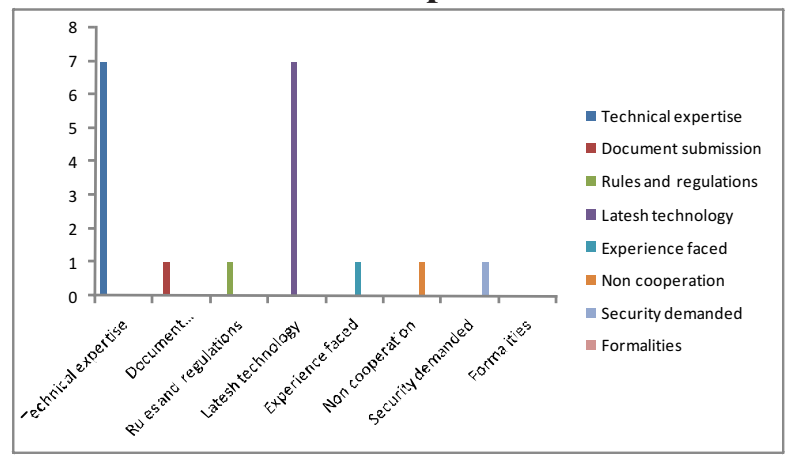


Table No. 3 : Problems faced at the later stage with the venture capitalists

Graph showing Problems faced at the later stage with the venture capitalists

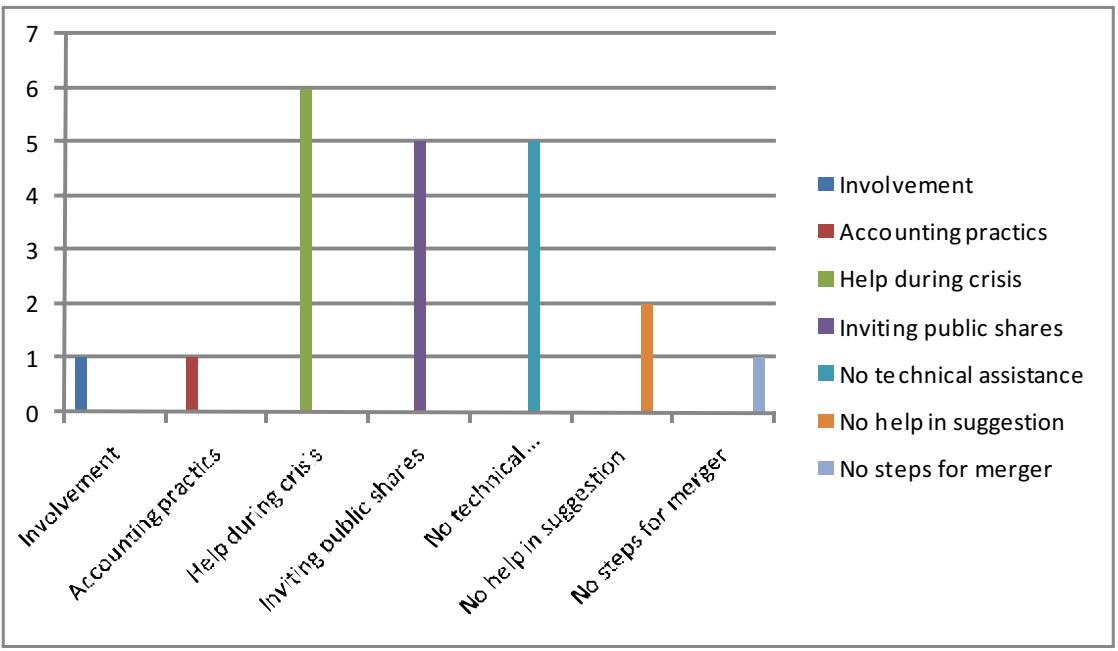


As per the Table No. 3, 30 percent are at the opinion that lack of involvement by venture capitalists during crisis, 24 percent are at the opinion that no technical assistance is being provided by venture capitalists, 24 percent are at the opinion that venture capitalists do not help in inviting for public shares and listing in stock exchanges, 10 percent are at the opinion that venture capitalist do not help in suggesting various methods for the improvement of the firm, 4 percent are at the opinion that the Venture capitalist do not take up necessary steps for mergers/takeovers/ acquisitions of the companies, 4 percent are at the opinion that too much of involvement by the venture capitalist in various stages of development of the company and 4 percent are at the opinion that frequent changes in accounting practices

Every coin has two sides. Let us see the problems faced by the venture capitalists while dealing with entrepreneurs

Table No. 4 : Data Analysis of Venture capitalist Nature of the company that the assistance has been given

Graph showing Nature of the company that the assistance has been given

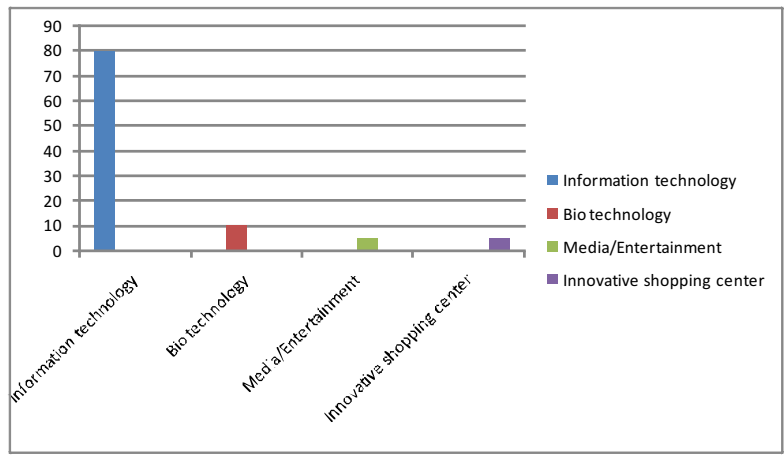


As it appears in Table No. 4 about 80 percent of the Venture capitalist have assisted Information technology oriented companies, 10 percent to Bio-technology oriented, and 5 percent to media/entertainment and innovative shopping centers

Table No. 5 : Problems faced while striking a Deal

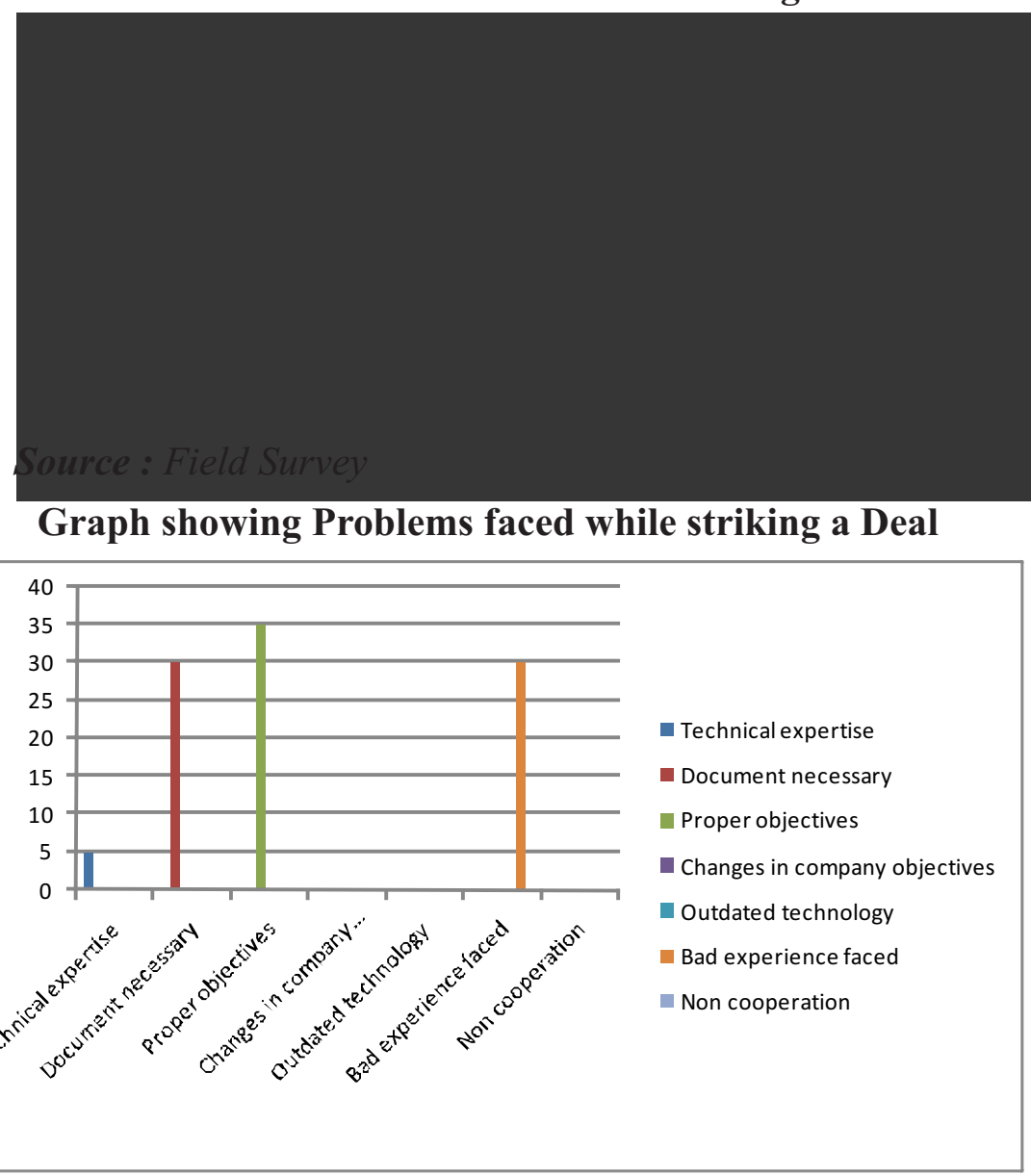

Table No. 5 indicates that about 35 percent of Venture capitalist are at the opinion that entrepreneur lack proper objectives, 30 percent of the Venture capitalist are at the opinion that entrepreneurs lack necessary documents in their company and bad experience faced by similar organizations in the past make it difficult to strike a deal and 5 percent of the Venture capitalist are at the opinion that entrepreneurs lack technical expertise in the company. 
Table No. 6 : Problems faced while exiting from the deal

According to figures shown in Table No. 6 about 50 percent of the Venture capitalist face problem while inviting for public shares and listing in stock exchanges and 50 percent of the Venture capitalist face problem while taking up necessary steps for mergers/takeovers/acquisitions of the companies.

\section{Graph showing Problems faced while exiting from the deal}

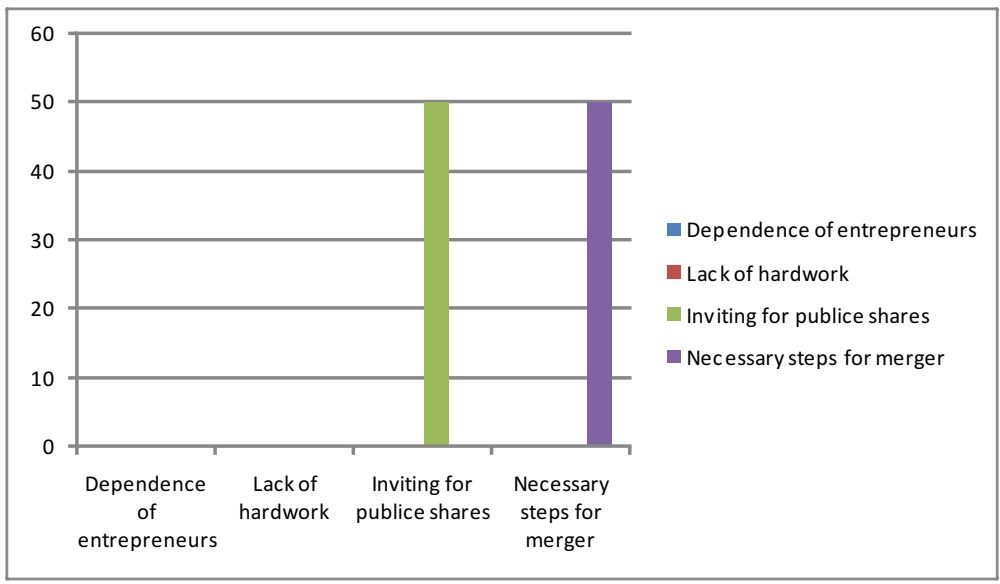

\section{Findings}

The study brings out the following findings:

- Most of the entrepreneurs have taken early stage, second round of financing. This means that the entrepreneurs need the finance when the product is launched in the market and experience lack of funds to attract the consumers/customers. At this stage, most part 
of Venture capital investment is in the form of debt to provide some financial support to the entrepreneur

- Lack of technical expertise and lack of awareness about the latest technology by Venture capitalists makes the entrepreneurs difficult to strike the deal

- Lack of involvement of Venture capitalists during crisis, help in the process of inviting public shares, listing in stock exchanges and provision of technical help are some of the major problems faced by entrepreneurs at the earlier stage.

- The Venture capitalists do not have sufficient skill and technically qualified persons in their organizations

- The entrepreneurs are at the opinion that the Venture capitalists should have very good interaction with them and customers and have very good job knowledge

- Most Venture capitalists do not assist entrepreneurs technologically, during crisis

- Most of the entrepreneurs prefer quarterly inspection/checking on them from Venture capitalists.

- Most entrepreneurs expressed the view that Venture capitalists should have sufficient technically qualified people so that they can serve better. About 45 percent of the entrepreneurs are at the opinion that Venture capitalists help is required in exiting from the deal and do not need any quality suggestions for their improvement. This means that the entrepreneurs can grow by themselves and do not need any kind of help in getting them improved. They also expect that sufficient management skills and expertise should be available in Venture capitalist organizations.

- When asked about the skills of employees of the venture capitalists should posses, it was noticed that the venture capitalists should have the idea about what the entrepreneurs are into. Without this, it was felt that it is very difficult for the entrepreneurs to convince the venture capitalist about their work. The other managerial skills that the entrepreneurs prefer are good communication skills, good interaction with the customers and 
among themselves. They also expect good attitude towards the complaint.

- One positive aspect that was noticed was that about 60 percent of the entrepreneurs were satisfied with their venture capitalist and given the chance to deal with them again, they are also in the opinion that their venture capitalists listen to their problems, and oblige for delayed payment.

\section{The data analysis of venture capitalists, indicates the following facts}

- It has been found that 55 percent to 90 percent of venture capitalists provide start up and second round of assistance in early stages. 40 percent of venture capitalists provide mezzanine/development capital and bridge/expansion type of finance at later stage.

- About 80 percent of the venture capitalists have assisted to information technology-oriented companies.

- Most venture capitalists prefer that the entrepreneurs possess the following qualities:

- Advanced technology, Honesty and sincerity, Good quality work, Good management skill and expertise, Good financial backup of the company and knowledgeable technical staff and expertise.

- Lack of necessary documents, lack of proper objectives and bad experience faced from similar organization of the entrepreneurs in the past make the venture capitalists difficult for striking a deal with new entrepreneurs.

- Inviting for public shares and listing in stock exchange, taking up necessary steps for merger/takeover/acquisition of the companies are the main problems faced by the venture capitalist while exiting from the deal from the entrepreneurs.

- Only about 41-60 percent, venture capitalist are successful from exiting from deal.

- About 61 to 80 percent of entrepreneurs are co-operative and follow all rules and regulations set by the venture capitalists. 
- Venture capitalist opt to carry out inspections of their entrepreneurs every half yearly once

- Most of the venture capitalists take feedback about them regularly.

- Most of the venture capitalists consider that the feedback about their functioning is very important to them.

- Most of the venture capitalists feel that the existing rules and regulations set by the government/SEBI can be liberalized especially regarding tax matters. Most of the venture capitalist are of the opinion that there cannot be any standard suggestions/framework to sort out or reduce the existing problems.

- The other problem that the venture capitalist faces from the entrepreneur is that the entrepreneurs do not try to invest anything and expect the whole amount to be invested by venture capitalists. This makes them very difficult to exit from the deal. Hence, the venture capitalist expects a strategic investment from entrepreneurs also.

- The difficult recovery strategies that venture capitalist follow are:

1 Sampling Method: Convenient random sampling by having a security in terms of mortgage on fixed assets.

2 by personal guarantee from the promoter

3 pledge of shares held by the promoters in the company.

\section{Suggestions}

- Most of the entrepreneurs have taken early stage, second round of financing. This means that the entrepreneurs need the finance when the product is launched in the market and it experiences shortage of funds to attract the consumers/customers. At this stage, most part of venture capital investment is in the form of debt to provide some financial support to the entrepreneur.

- Lack of technical expertise and awareness about the latest technology by the venture capitalist makes the entrepreneur very difficult to strike the deal. The managerial skills that the venture 
capitalist must possess are good communication skills, good interaction with the customers and among themselves.

- About 45 percent of entrepreneurs are at the opinion that the venture capitalist must help them in exiting from the deal and do not need any quality suggestions for their improvement. Hence, it is recommended that the venture capitalist take active steps while exiting from the deal by publishing the entrepreneurs in stock exchange/invite for shares etc.

- One positive that was noticed was that about 60 percent of the entrepreneurs are satisfied with their venture capitalists and given the chance to deal with them again; they would do so with their venture capitalists. They are also in the opinion that their venture capitalists listen to their problems and oblige for delayed payment.

- Lack of necessary documents, lack of paper objectives and bad experience faced from similar organizations of the entrepreneurs in the past make the venture capitalists difficult while striking a deal with new entrepreneurs. Hence, it is recommended that the entrepreneurs possess proper objectives/have proper project report supported with all necessary documents which makes the venture capitalists easy to assist them.

- It was also noticed that most of the assistance taken are by Information Technology oriented companies. It is recommended that even the other kind of organizations come forward to avail this kind of assistance the venture capitalists should provide necessary assistance.

- The venture capitalists are also under the opinion that the entrepreneurs are not co-operative while existing from the deal especially if it requires the company to be merged with others or if it involves buy-outs or buy ins. Hence, it is recommended that the entrepreneurs should co-operate with the venture capitalists to carry out the above-mentioned activities which will be beneficial to both the parties.

- The venture capitalists feel that the existing rules and regulations set by the government/SEBI can be liberalized especially 
regarding tax matters. Most of the venture capitalists are under the opinion that there cannot be any standard suggestion/framework to sort out or reduce the existing problems. Hence it is recommended that the existing rules and regulations can be liberalized especially in tax matters.

- The other problem that the venture capitalists face from the entrepreneur is that the entrepreneurs do not try to invest anything and except the whole amount to be invested by venture capitalists. This makes them very difficult to exit from the deal. Hence, it is recommended that the entrepreneurs also invest some part (say about 15 percent - 20 percent) of the total projected cost.

\section{Conclusion}

The growth of venture capital has been drastically decreasing due to many reasons. But the venture capital has made many contributions to the growth of developed countries. The slow growth of venture capital in India appears to be due to various factors on the part of venture capitalists as well as entrepreneurs. These factors include lack of involvement, Accounting practices, No help during crisis, No technical assistance from the venture capitalist etc. and the data analysis of venture capitalist shows that more assistance is given to information technology based companies than other companies and the problems faced by the venture capitalist is the lack of document submitted, no proper objectives, frequent changes, outdated technology, lack of hard work, problem while merger etc. Most of the venture capitalists prefer the entrepreneur having good management skills good quality work and good financial back up of the company and he also uses many strategies to recover the funds through mortgage on fixed assets, personal guarantee, pledge etc. So there are many problems faced by the both venture capitalist and entrepreneur, so by having all the necessary requirements including the documents skills proper procedure, the of venture capital system can be implemented in India successfully which can contribute to India's growth. 


\section{References}

Robert D Hisrich, Michael P Peters, Dean A Shepherd, (2007), "Entrepreneurship", Tata McGraw-Hill Publishing Company Limited, New Delhi, Sixth edition.

Vasant Desai, 2009), "Dynamics of Entrepreneurial Development and Management", Himalayan Publishing House, New Delhi, Millennium Edition.

David L Bodde, (2004), “The Intentional Entrepreneur”, Prentice Hall of India, New Delhi

International Journal of Management and Social Science Research Review, (2017), Volume No-1, Issue No-31, Impact factor- 3.996, Bangalore

A K PC Swain, (2007), "Research Methodology" Kalyani Publishers, Bangalore, Second Revised Edition

www.investopedia.com/terms/v/venturecapitalist.asp\#ixzz4d1JvrW hd

Watson J, (2003), "Failure rates for female-controlled business: Are they different"? Journal of Small Business Management, 41(3), pp.262-277

Mohanty.B, "Development of Enterprise in Industry", New Delhi, Cyber Tech 